\title{
AKTIVITAS ANTIBAKTERI TUMBUHAN PRINJAK (Aleurites moluccana (L.)) TERHADAP BAKTERI SALMONELLA THYPOSA DAN VIBRIO CHOLERA
}

\author{
Arsyik Ibrahim \\ Bagian Biologi-Mikrobiologi Farmasi, UP. Fakultas Farmasi, Universitas Mulawarman, Samarinda, \\ Kalimantan Timur \\ e-mail : achie.ibrahim@gmail.com
}

\begin{abstract}
A research which antibacterial activity test from Prinjak plant (Aleurites moluccana (L.) Willd to several pathogens bacterial, which aims to determine the antibacterial activity of bark prinjak (A. moluccana L.) against bacteria Salmonella thyposa and Vibrio cholerae. Extracts used is crude methanol extract. Examination of antibacterial with Minimum Kill Concentration (KBM) method, and followed by agar diffusion method with using paper disks. ANOVA analisis test it is obtained very significant results, followed by BNJ advanced test, BNJ test obtained the best concentration is $1.75 \%$ results of the bacteria Salmonella and Vibrio cholerae thiposa.
\end{abstract}

Key words: A. moluccana L. Willd, antibacterial activity, S. thiposa, V.cholera

\begin{abstract}
ABSTRAK
Telah dilakukan penelitian Aktivitas Antibakteri Tumbuhan Prinjak (Aleurites moluccana (L.) terhadap Beberapa Bakteri Patogen, yang bertujuan untuk mengetahui aktivitas antibakteri kulit batang prinjak (A. moluccana (L.) Willd., terhadap bakteri Salmonella thyposa dan Vibrio cholera. Ekstrak yang digunakan adalah ekstrak kasar metanol. Metode uji yang digunakan adalah uji Daya Bunuh Minimum (KBM), dan dilanjutkan dengan metode difusi agar menggunakan paper disk. Hasil analsisis uji ANOVA aktivitas antibakteri diperoleh hasil yang sangat signifikan, dilanjutkan dengan uji lanjutan BNJ, hasil uji BNJ diperoleh konsentrasi terbaik adalah 1,75\% terhadap bakteri Salmonella thiposa dan Vibrio cholera.
\end{abstract}

Kata kunci: A. moluccana L. Willd, aktivitas antibakteri, S. thiposa, V.cholera

\section{PENDAHULUAN}

Suku Dayak Tunjung merupakan suku mayoritas yang mendiami Kabupaten Kutai Barat, Kalimantan Timur, sejak puluhan atau bahkan ratusan tahun yang lalu, hutan dan hasil-hasil dari hutan telah memberi kehidupan bagi masyarakat Dayak Tunjung di wilayah ini. Pengembangan tanaman obat melalui budidaya in vitro, budidaya tanaman langka dan baru serta punya nilai pasar yang tinggi yang kini terus digiatkan, diharapkan menambah jumlah atau spesies tanaman obat, yang pada gilirannya akan dapat mengurangi ketergantungan impor bahan baku obat-obatan sehingga dapat bersaing [1].

Pencarian senyawa selalu dibarengi dengan uji aktivitas (bioassay guided isolation) sehingga hasil penelitian yang dihasilkan memiliki kemanfaatan bagi pengembangan ilmu pengetahuan dan obat dari bahan alam, hal ini membuka kemungkinan perluasan penelitian tanaman obat yang berasal dari daerah lain, termasuk 
Aktivitas Antibakteri Tumbuhan Prinjak (Aleurites moluccana (1.)) Terhadap Bakteri Salmonella thyposa dan Vibrio cholera

Kalimantan Timur yang sumber daya hayatinya belum dikembangkan dan dimanfaatkan secara optimal.

Tumbuhan obat yang telah dimanfaatkan dan dipercayai masyarakat Indonesia khususnya Kalimantan Timur diantaranya tumbuhan prinjak (A. moluccana (L) Willd). Tumbuhan prinjak tidak hanya buahnya saja yang dimanfaatkan tetapi ternyata salah satu suku di Kalimantan Timur ini yaitu suku Dayak memanfaatkan kulit batang kemiri sebagai suatu pengobatan penyakit yang disebabkan oleh bakteri yaitu demam typhus.

Prinjak atau candle nut adalah tanaman dari famili Euphorbiaceae, berkhasiat untuk mengobati buang air besar yang mengandung darah, diare, disentri, sakit perut, sembelit, demam, sariawan, sakit gigi, bisul, kapalan, rambut rontok, dan dapat menyuburkan rambut. Kandungan senyawa kulit batang Kemiri seperti yang dinyatakan Duke (1983) mengandung senyawa tanin.

Penelitian ini bertujuan mengetahui aktivitas antibakteri kulit batang prinjak ( $A$. moluccana (L) Willd) terhadap beberapa bakteri patogen.

\section{METODE}

\section{Bahan}

Aquadest, Dimetil Sulfo Oksid (DMSO), medium GNA, pelarut organik (metanol tehnis), kulit batang prinjak (A. moluccana (L) Willd.

Biakan Mikroba Uji: strain-strain mikroba: S. thyposa, dan V. cholera

\section{Alat}

Seperangkat alat ekstraksi maserasi, seperangkat alat evaporator, seperangkat alat sterilisasi (oven, auto clove), seperangkat alat inkubator, timbangan analitik, alat-alat gelas, mikro pipet, vortex mixer, laminar air flow (LAF), drigle sky, lampu spiritus

\section{Pengolahan sampel penelitian.}

Kulit batang A. moluccana (L) Willd, yang telah dikumpulkan dipisahkan bagian yang tidak diperlukan selanjutnya dibersihkan dan dicuci dengan air, kemudian dianginanginkan hingga kering di tempat yang tidak terpapar langsung sinar matahari. Kulit yang telah kering kemudian dipotong-potong kecil dan siap digunakan sebagai bahan penelitian.

\section{Ekstraksi dan partisi.}

Sebanyak 500 gram kulit batang $A$. moluccana (L) Willd. kering, di serbukkan, kemudian diekstraksi secara maserasi menggunakan cairan penyari metanol selama 3 x 24 jam. Filtrat disaring dan residu direndam lagi dalam pelarut yang sama. Filtrat dikumpulkan dan diuapkan menggunakan rotavapor hingga diperoleh ekstrak metanol kental, selanjutnya ekstrak kental diuapkan pelarutnya hingga diperoleh ekstrak metanol kering kulit batang prinjak.

\section{Pengujian Kadar Bunuh Minimum.}

Ekstrak metanol kering kulit batang prinjak, diuji aktivitasnya terhadap mikroba uji dengan metode dilusi padat. Pengujian dilakukan dengan menimbang $10 \mathrm{mg}$ ekstrak, kemudian dimasukkan ke dalam vial steril dan dilarutkan dengan $200 \mu 1(0,2 \mathrm{ml})$ DMSO dan dicampur hingga homogen dengan 9,8 ml medium GNA, konsentrasi ekstrak dalam medium uji adalah $1 \mathrm{mg} / \mathrm{ml}$. Campuran ekstrak dan medium GNA dituang ke dalam cawan 
Aktivitas Antibakteri Tumbuhan Prinjak (Aleurites moluccana (1.)) Terhadap Bakteri Salmonella thyposa dan Vibrio cholera

Petri steril dan dibiarkan memadat. Tiap cawan Petri dibagi dua zona untuk 2 bakteri uji. Setelah media memadat ke dalam masing-masing cawan Petri ditambahkan $20 \mu l$ suspensi bakteri $S$. thyposa dan V.cholera. Diinkubasikan pada suhu $37^{\circ} \mathrm{C}$ selama 24 jam [4].

\section{Pengujian Difusi Agar.}

Disiapkan alat dan bahan yang akan digunakan dan yang telah disterilkan. Kemudian dibuat pengenceran dari ekstrak metanol kulit batang prinjak dengan beberapa variasi konsentrasi berdasarkan hasil uji KBM. Selanjutnya ke dalam cawan Petri steril dimasukkan 0,02 ml suspensi mikroorganisme, kemudian medium Nutrien Agar dituang ke dalam cawan Petri yang berisi suspensi mikroorganisme, dibiarkan sampai memadat. Selanjutnya dicelupkan paper disc ke dalam larutan ekstrak uji. Kontrol positif Ciprofloxacin diperlakukan sama dengan cara pengujian sampel uji. Paper disc diletakan di atas media inokulum yang telah memadat, diinkubasi selama 1 x 24 jam pada suhu $37{ }^{\circ} \mathrm{C}$ dan diamati zona hambatan yang terbentuk dan dilakukan pengukuran garis tengah daerah hambatan/bunuh dengan menggunakan mikrometer sekrup [4].

Data penelitian aktivitas ekstrak metanol kulit batang prinjak berupa data kualitatif dengan melihat pembunuhan pertumbuhan bakteri uji merupakan data Kadar Bunuh Minimum, dan data zona hambat/bunuh berupa data kuantitatif dengan mengukur luas zona hambat/bunuh ekstrak uji. Analisis data akhir dari aktivitas ekstrak metanol kulit batang prinjak adalah analisis zona hambat/bunuh secara kuantitatif dengan metode ANOVA dan dilanjutkan dengan uji Beda Nyata Jujur (BNJ). Hasil uji BNJ digunakan untuk

J. Trop. Pharm. Chem. 2011. Vol 1. No. 3. menentukan konsentrasi terbaik dari ekstrak terhadap bakteri uji [6].

\section{HASIL DAN PEMBAHASAN}

\section{A. Penyarian Sampel}

Sampel kulit batang A. moluccana (L) Willd yang telah dikumpulkan dibersihkan dan dicuci dengan air untuk menghilangkan jamur yang melakat pada permukaan epidermis kulit, selanjutnya dikeringkan pada tempat yang tidak terpapar langsung sinar matahari. Selanjutnya kulit yang telah kering kemudian diserbukkan dan direndam dalam cairan penyari metanol. Penggunaan cairan penyari metanol pada penelitian ini karena bersifat semipolar sehingga dapat menyari komponen kimia yang bersifat polar maupun non polar, sehingga diharapkan semua komponen kimia dalam sampel relatif akan terekstraksi.

Proses penyarian dilakukan berulang-ulang dengan menganti cairan penyari yang baru pada sampel yang sama hingga penyarian sempurna (cairan pelarut nampak tidak berwarna). Ekstrak metanol yang diperoleh kemudian dipekatkan menggunakan rotavapor sampai diperoleh ekstrak metanol kental, selanjutnya dilakukan penguapan maksimal hingga ekstrak menjadi kering, ekstrak metanol kering diperoleh sebanyak 488,0 gram.

\section{B. Uji Antibakteri}

\section{Kadar Bunuh Minimum}

Hasil uji aktivitas antibakteri ekstrak kulit batang prinjak dengan menggunakan metode Kadar Bunuh Minimum (KBM). Tujuan pengujian ini adalah uji skrinning aktivitas awal untuk mengetahui kemampuan daya bunuh ekstrak berdasarkan variasi konsentrasi dan 
Aktivitas Antibakteri Tumbuhan Prinjak (Aleurites moluccana (1.)) Terhadap Bakteri Salmonella thyposa dan Vibrio cholera

membandingkan efek ekstrak yang menghasilkan daya bunuh paling kuat terhadap bakteri uji. Pengujian KBM menggunakan bakteri Salmonella typhosa dan Vibrio cholerae, dengan 4 konsentrasi uji yaitu $0,5 \%, 1 \%$, dan $1,5 \%$. Hasil uji KBM di tunjukkan oleh Tabel 1.

Tabel 1. menunjukkan pada konsentrasi $1 \%$ aktivitas antibakteri menunjukkan ekstrak memberikan aktivitas daya hambat, sedang pada konsentrasi $1,5 \%$ menunjukkan daya bunuh dengan parameter zona yang jernih. Semakin tinggi konsentrasi ekstrak kulit batang kemiri, maka semakin besar pula zona bening yang dihasilkan.

\section{Aktivitas Antibakteri Ekstrak Kulit Batang Prinjak}

Pengujian Aktivitas antibakteri ekstrak Kulit Batang Prinjak menggunakan 3 deret konsentrasi yaitu: $1,25 \%, 1,5 \%$, dan $1,75 \%$, penentuan deret konsentrasi uji berdasarkan deret ukur, dengan metode pengujian menggunakan metode difusi agar. Aktivitas antibakteri ditentukan berdasarkan diameter zona bunuh dengan parameter pengamatan adalah zona bening. Diameter zona bunuh dari masing-masing konsentrasi ekstrak uji selanjutnya dihitung nilai rata-rata dengan pembanding negatif adalah aquadest. Hasil pengukuran aktivitas antibakteri ekstrak kulit batang Prinjak dapat di lihat pada Tabel 2.

Tabel. 1 Hasil Uji Kadar Bunuh Minimum (KBM) ekstrak metanol kulit batang Kemiri terhadap bakteri S. thyposa dan V. cholera

\begin{tabular}{|c|c|c|c|c|}
\hline \multirow{2}{*}{ No } & \multirow{2}{*}{ Bakteri Uji } & \multicolumn{3}{|c|}{ Konsentrasi } \\
\hline & & $0,5 \%$ & $1 \%$ & $1,5 \%$ \\
\hline 1. & Salmonella thyphosa & - & + & ++ \\
\hline 2. & Vibrio cholerae & - & + & ++ \\
\hline
\end{tabular}

Tabel 2. Rata-rata diameter zona bunuh dari beberapa variasi konsentrasi uji ekstrak kulit batang Prinjak terhadap bakteri $S$. thyposa dan V. cholera

\begin{tabular}{ccccc}
\hline \multirow{2}{*}{ Perlakuan (Y) } & \multicolumn{3}{c}{ Zona Bening Ekstrak $(\mathbf{m m})$} & \multirow{2}{*}{ Aquadest } \\
\cline { 2 - 4 } & $\mathbf{1 , 2 5} \%$ & $\mathbf{1 , 5 \%}$ & $\mathbf{1 , 7 5 \%}$ & \\
\hline S. thyphosa & $\mathbf{6 , 6 7}$ & $\mathbf{7 , 7 3}$ & $\mathbf{9 , 4 3}$ & 0 \\
V. cholerae & $\mathbf{8 , 0 6}$ & $\mathbf{9 , 6 4}$ & $\mathbf{1 2 , 4 6}$ & 0 \\
\hline
\end{tabular}

Konsentrasi uji $1,75 \%$ menunjukkan aktifitas antibakteri yang paling besar dilihat dari rata-rata diameter zona bening yang dihasilkan dari 2 (dua) replikasi baik pada bakteri uji $S$. typhosa maupun pada $V$. cholerae (Tabel 2). Aktifitas terbaik ekstrak terhadap bakteri S. typhosa dan $V$. cholera adalah pada konsentrasi $1,75 \%$, dengan diameter rata-rata zona bening adalah $9,43 \mathrm{~mm}$ untuk S. Thiposa dan 12,46 mm untuk $V$. cholera. Perbedaan aktivitas ekstrak terhadap kedua bakteri ini disebabkan oleh perbedaan sifat secara fisiologi dimana $S$. typhosa diameter aktivitasnya cenderung lebih kecil oleh karena bakteri $S$. typhosa memiliki antigen $\mathrm{O}$ (somatic) yang tahan terhadap pemanasan $100{ }^{\circ} \mathrm{C}$, senyawa fenol, 
Aktivitas Antibakteri Tumbuhan Prinjak (Aleurites moluccana (1.)) Terhadap Bakteri Salmonella thyposa dan Vibrio cholera

senyawa bersifat asam. Berbeda halnya dengan bakteri $V$. cholerae yang tidak terhadap asam. Kontrol negatif

(pembanding) aquadest tidak menghasilkan daerah zona bening.

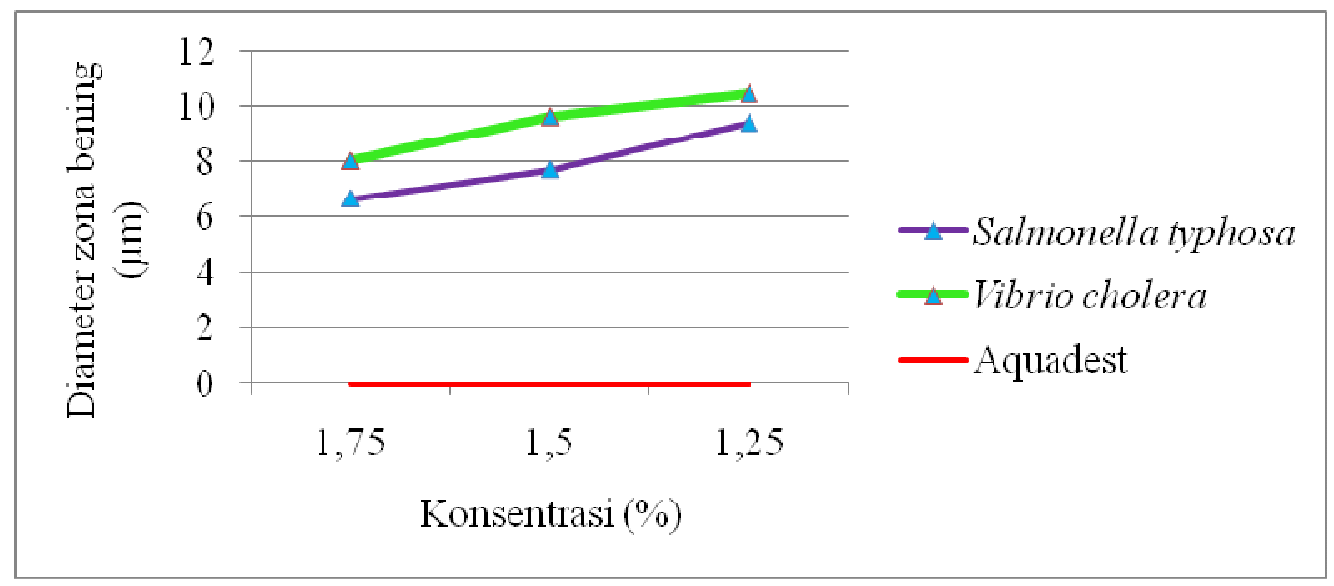

Gambar 1. Grafik pengaruh konsentrasi ekstrak kasar kulit batang Prinjak dibandingkan dengan aquadest

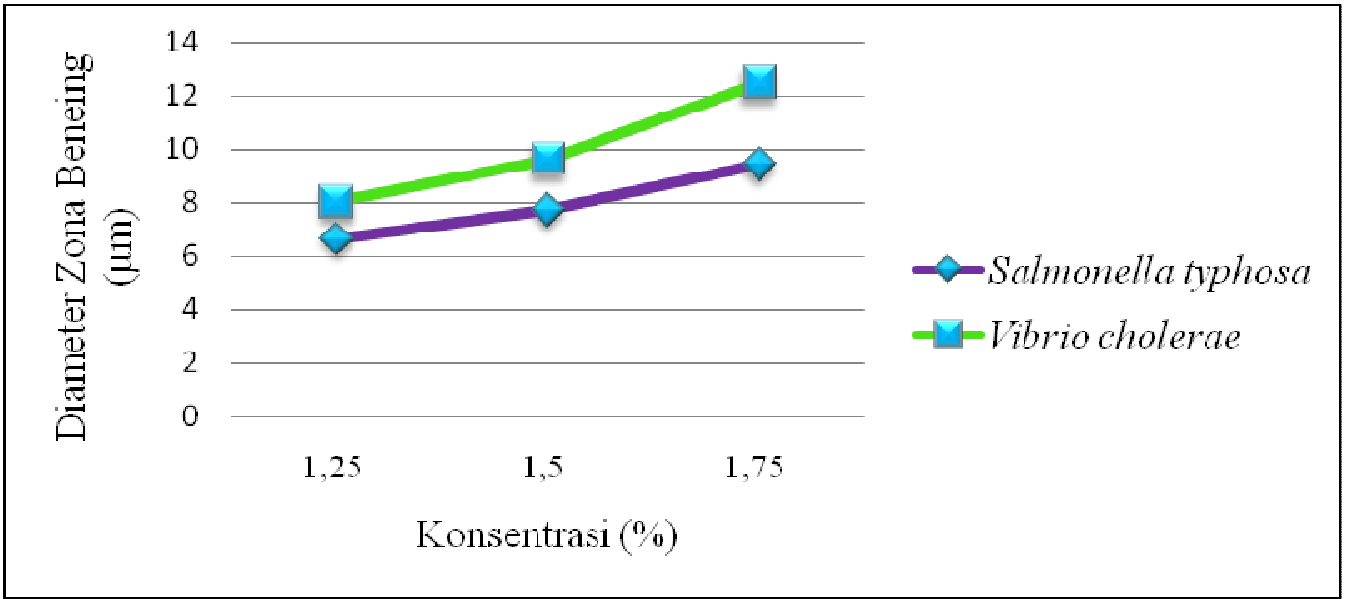

Gambar 2. Grafik pengaruh konsentrasi ekstrak kulit batang kemiri

\section{Konsentrasi Terbaik Ekstrak Kulit Batang Prinjak Sebagai Antibakteri}

Pengujian uji daya hambat ekstrak dilakukan untuk mengetahui seberapa besar kemampuan ekstrak dari berbagai konsentrasi yang dapat menghambat ataupun membunuh bakteri dengan zona bening yang dihasilkan ekstrak sebagai parameter uji. Zona bening merupakan aspek utama dalam mengetahui aktifitas antibakteri.
Gambar 1 menunjukkan adanya sedikit perbedaan efektifitas antibakteri terhadap dua jenis bakteri yaitu Salmonella thiphosa dan Vibrio cholerae. Terlihat bahwa zona yang dihasilkan oleh tiap konsentrasi terhadap bakteri Vibrio cholerae lebih besar dibandingkan dengan bakteri Salmonella thiphosa walaupun kedua bakteri ini merupakan sama-sama bakteri gram negatif.

Namun kesamaan dari aktifitas terhadap dua bakteri ini adalah adanya peningkatan 
Aktivitas Antibakteri Tumbuhan Prinjak (Aleurites moluccana (1.)) Terhadap Bakteri Salmonella thyposa dan Vibrio cholera

yang sama terhadap zona hambat yang terjadi oleh karena peningkatan konsentrasi.

Dari Gambar 2 tersebut juga terlihat konsentrasi terbaik sebagai antibakteri adalah konsentrasi $1,75 \%$.

\section{a) Bakteri Salmonella typhosa}

Data aktivitas antibakteri ekstrak metanol batang prinjak pada Tabel 2. Selanjutnya dianalisis dengan ANOVA untuk mengetahui atau menjelaskan bahwa aktifitas antibakteri ekstrak kulit batang Prinjak pada tiap variasi konsentrasi memiliki pengaruh antara satu dan lainnya.

Hasil perhitungan analisis ANOVA tertera dalam Tabel 3.

Tabel 3. Pengujian daya hambat terhadap Salmonella thyphosa dengan metode ANOVA

\begin{tabular}{|c|c|c|c|c|c|c|c|}
\hline \multirow{2}{*}{$\begin{array}{c}\text { Sumber } \\
\text { Keragaman }\end{array}$} & \multirow{2}{*}{$\mathrm{Db}$} & \multirow{2}{*}{ JK } & \multirow{2}{*}{ KT } & \multirow{2}{*}{ F Hitung } & \multicolumn{2}{|c|}{ F Tabel } & \multirow{2}{*}{ Ket } \\
\hline & & & & & $5 \%$ & $1 \%$ & \\
\hline Ekstrak & 2 & 7,78 & 3,89 & 129,66 & 9,55 & 30,81 & $\mathrm{~S}$ \\
\hline Galat & 3 & 0,11 & 0,03 & & & & \\
\hline Total & 5 & 7,89 & 3,92 & & & & \\
\hline
\end{tabular}

Tabel 4. Tabel perbandingan nilai beda dan nilai BNJ terhadap aktifitas antibakteri Salmonella thyphosa

\begin{tabular}{ccccc}
\hline Perlakuan & Rata-Rata & \multicolumn{3}{c}{ Nilai beda } \\
\cline { 3 - 5 } (konsentrasi) & (zona bunuh) & $1,25 \%$ & $1,5 \%$ & $1,75 \%$ \\
\hline $1,25 \%$ & 6,67 & - & - \\
$1,5 \%$ & 7,73 & $1,06^{* *}$ & $1,7 * *$ & - \\
$1,75 \%$ & 9,43 & $2,76^{* *}$ & $\mathrm{BNJ}_{0,05}=0,545$ & BNJ $_{0,01}=0,28$ \\
\hline BNJ & & &
\end{tabular}

Tabel 5.Hasil perhitungan ANOVA ekstrak metanol kulit batang kemiri terhadap daya hambat terhadap Vibrio cholerae dengan metode ANOVA

\begin{tabular}{cccccccc}
\hline $\begin{array}{c}\text { Sumber } \\
\text { Keragaman }\end{array}$ & \multirow{2}{*}{$\mathrm{Db}$} & \multirow{2}{*}{$\mathrm{JK}$} & KT & F Hitung & \multicolumn{2}{c}{ F Tabel } & \multirow{2}{*}{ KET } \\
\hline Ekstrak & 2 & 19,87 & 9,93 & 4,57 & 9,55 & 30,81 & \multirow{2}{*}{ NS } \\
Galat & 3 & 6,52 & 2,17 & & & & \\
\hline Total & 5 & 26,39 & 12,1 & & & & \\
\hline
\end{tabular}

Hasil analisis ANOVA diperoleh nilai $\mathrm{F}$ hitung sebesar 129,66 lebih besar dibandingkan dengan $\mathrm{F}$ tabel 5\% maupun 1 $\%$. Hal ini menunjukkan bahwa ada perbedaan nyata pengaruh daya hambat antar konsentrasi uji. Nilai koefisien keragaman (KK) efek daya bunuh masingmasing konsentrasi uji adalah 2,14\%. Analisis data dilanjutkan dengan uji BNJ (Beda Nyata Jujur) yang bertujuan untuk mencari konsentrasi terbaik diantara variasi konsentrasi uji. Syarat analisis BNJ adalah nilai koefisien keragaman maksimal 5\%.

Hasil uji BNJ terhadap bakteri Salmonella thyphosa (Tabel 4.) diperoleh nilai sangat signifikan antara konsentrasi $1,75 \%$ dengan $1,25 \%$ dan $1,75 \%$ dengan $1,5 \%$ dimana t-hitung masing-masing 2,76 dan 1,7 lebih besar dari $\mathrm{t}$-tabel $\mathrm{t}_{0,05}=0,545$ maupun $\mathrm{t}$-tabel $\mathrm{l}_{0,01}=0,28$. Hasil ini menunjukkan bahwa konsentrasi antibakteri terbaik ekstrak metanol kulit 
Aktivitas Antibakteri Tumbuhan Prinjak (Aleurites moluccana (1.)) Terhadap Bakteri Salmonella thyposa dan Vibrio cholera

batang Prinjak terhadap bakteri S. typhosa adalah $1,75 \%$.

\section{b) Bakteri Vibrio cholera}

Data aktivitas antibakteri ekstrak metanol kulit batang prinjak terhadap bakteri $V$. cholera pada Tabel 2 selanjutnya dianalisis dengan ANOVA untuk mengetahui atau menjelaskan bahwa aktifitas antibakteri ekstrak kulit batang Prinjak pada tiap variasi konsentrasi memiliki pengaruh antara satu dan lainnya. Hasil perhitungan analisis ANOVA tertera dalam Tabel 5.

Hasil analisis ANOVA diperoleh nilai $\mathrm{F}$ hitung lebih kecil dari F-tabel yaitu 4,57 dibandingkan dengan $\mathrm{F}$ tabel $5 \%=9,55$ dan $1 \%=30,81$. Hasil analisis tersebut menunjukkan tidak adanya perbedaan nyata pengaruh daya hambat antara konsentrasi uji.

\section{KESIMPULAN}

Berdasarkan hasil penelitian dapat disimpulkan bahwa:

1. Kadar Bunuh Minimum (KBM) ekstrak metanol kulit batang Prinjak (A. Moluccana (L) Willd. terhadap bakteri $S$. thyposa dan $V$. cholera adalah pada konsentrasi $1,5 \%$

2. Konsentrasi terbaik ekstrak metanol kulit batang Prinjak terhadap bakteri
Salmonela thyposa dan bakteri Vibrio cholera adalah pada konsentrasi $1,75 \%$

\section{UCAPAN TERIMA KASIH}

Ucapan terima kasih kepada Pimpinan Fakultas UP. Fakultas Farmasi yang telah memberikan dana penelitian, dan kepada kepala Laboratorium Biologi dan Mikrobiologi dan Laboratorium Bahan Alam UP. Fakultas Farmasi UNMUL yang telah memberikan izin menggunakan laboratorium untuk penelitian.

\section{DAFTAR PUSTAKA}

1. Badan Pusat Statistik. 2001, Kabupaten Kutai Barat. $\quad$ http://wikipedia.co.id/Kabupaten KutaiBarat [diakses tanggal 19 April 2009]

2. Duke, J.A. 1991, Handbook of Medicinal Herbs, U.S.A.; CRC Press.

3. Direktorat Jenderal Pengawasan Obat dan Makanan. 1979, Sediaan Galenik, Departemen Kesehatan Republik Indonesia. Jakarta. 9

4. Djide, M.N.; \& Sartini. 2008, Analisis Mikrobiologi Farmasi. Laboratorium Mikrobiologi Farmasi Fakultas Farmasi Universitas Hasanuddin.; Makassar.

5. Jawetz, E. 1995, Mikrobiologi Untuk Profesi Kesehatan. Hal 299 - 303.; Jakarta.

6. Sugiyono. 2007, Statistika Untuk Penelitian. Alfabeta; Bandung. 